\title{
FLAVONOIDS OF THE LEAVES OF Quercus pontica
}

\author{
D. N. Enukidze and I. I. Moniava
}

UDC 547.972

From the total flavonoids of the leaves of Quercus pontica C. Koch. by chromatography on Sephadex G-75 we have isolated two individual substances: flavonoids A and B.

Flavonoid A formed light yellow acicular crystals with $\mathrm{mp} 177-178^{\circ} \mathrm{C}, \lambda \underset{\max }{\mathrm{C}_{\mathrm{H}} \mathrm{OH}} 266$ and $360 \mathrm{~nm}$. On acid hydrolysis it gave ka empferol $(68.5 \%)$ and D-glucose. On paper chromatograms in various solvent systems it appeared at the level of an authentic sample of astragalin. It gave no depression of the melting point with an authentic sample, and thus flavonoid A was identified as astragalin [1].

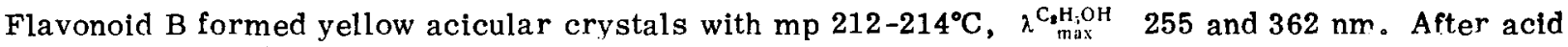
hydrolysis it gave quercetin $(66.5 \%)$ and D-glucose. On paper chromatograms in various systems of solvents it had the same mobility as a standard sample of isoquercitrin. It showed no depresslon of the melting point with an authentic sample.

The physicochemical properties of flavonoid B were identical with those of isoquercitrin [2].

This is the first time that astragalin has been found in the genus Quercus.

\section{LIT ERAT URE CITED}

1. P. R. Bhandari, J. Chromatogr., 16, No. 1, 130 (1969).

2. H. Rzodkowska-Badalska, Dissert. Pharmac. Pharmacol. 20, 3, 329 (1968).

I. G. Kutateladze Institute of Pharmacochemistry, Academy of Sclences of the Georgian SSR. Translated from Khimlya Prirodnykh Soedinenii, No.6, p. 834, November-December, 1971. Original article submitted June 17, 1971.

- 197.t Consultants Bureau, a division of Plenum Publishing Corporation, 297 II est 17th itrect, Veu Yorh, V. I. 10011. Vo part of this publication may be reproduced, stored in a retrieval system, or transmitted, in any form or by any means, electronic, mechanical, photocopying, microfilming, recording or otheruise, uithout uritten permission of the publisher. I copy of this article is available from the publisher for $\$ 1.5 .00$. 